\title{
INVESTIGATION ON THE PROFILE OF SOCIAL WORKER OCCUPATION IN BULGARIA
}

\author{
Venelin TERZIEV, Preslava DIMITROVA \\ "Vasil Levski" National Military University, Veliko Tarnovo, Bulgaria \\ terziev@skmat.com
}

\begin{abstract}
This paper presents the research interest to the occupation of the social worker in international scope and analyzes the essence of the social work in Bulgaria. The profile of the social worker rendering social services in Bulgaria is discussed and conclusions are made considering the need of building professional competences. The study poses important questions and puts the basics of further research in identification and monitoring of the needs of training of social activities experts.
\end{abstract}

Keywords: social worker, occupational training, social activities.

\section{INTRODUCTION}

The research interest to the occupation of the social worker manifests from the insufficiently clear profile in Bulgaria at the moment, according to the dynamic needs of population. Issues are discussed mainly related to what professionals the social activity experts are in essence, what are their rights, duties, responsibilities, which are the areas of realization, what are the models of occupational activity which shall be performed according to the example of other countries where the occupation of the social worker has traditions and accumulated good practices [1-3].

In July 2014 in Melbourne the Executive Committee of International Federation of Social Workers (IFSW) and International Association of Schools of Social Work (IASSW) reached consent that the review of the social worker's global definition has ended and a new definition for the occupation of the ,social work" was suggested [4], namely: Social work is occupation, based on the practice and academic discipline promoting social change and development, social cohesion and the empowerment and liberation of people. The principles of social justice, human rights, collective responsibility and respect to the differences are central for the social work. Based on the theories of social work, social science, humanitarian studies and knowledge of the native population, social work engages people and structures for dealing with the challenges of life and improvement of wellbeing. The aforementioned definition may be extended at national and/or regional level.

According to the recent editing of the Social Assistance Act (amended and completed Official Gazette issue No 8 dated 29 January 2016) in Bulgaria the social work is defined as follows [8]: Social work is an occupational activity for improvement of mutual adaptation of people, families, groups and environment they live in. It is a complex of supporting activities, directed towards achieving better quality of life, dignity and responsibility in people on the grounds of their individual abilities, inter- 
personal relations and resources of community.

Many structures and taxonomies have been established in order to assist the workers to get oriented in the social work theories. In its fundament many of the classifications reach to human nature discussions, the relative significance of biological, culture and experience in human development and social movements, defining and forming the human society [6]. One of the greatest divisions in social work theory creates two large academic disciplines - psychology and sociology through the prism of interstructural and psychological explanations of personal issues. With the structural perspectives the focus is on political, economic and material environment where people are - poverty and inequality, social injustice and the so-called „bad social functioning". In the practice most social work theories are strongly affected by the psychological perspective towards human behavior - the ways we develop, study and react. Attention is paid to the emotional side of people's lives and quality of their relations with children, parents and partners. Understanding, support, meeting emotional needs, control on experiences are accepted as approach to settling the problem. This approach includes several stages:

- $\quad$ identification, description and measurement of the problem;

- analysis of factors, including

behavior of other people creating the problem;

- selecting objectives to solve the problem;

- determining and performing those actions through which reached will be the objectives and solved will be the problems.

\section{PROFILE OF THE SOCIAL WORKER RENDERING SOCIAL SERVICES IN BULGARIA}

Identification of social worker's professional profile rendering various social services in Europe is complex having in mind that the European Union countries name in various ways experts, engaged with social work [5, 7, 9-24]. In the American and European literature sources attempts are made concluding the general occupational characteristics of the social worker [1-3, 25].

Most generally at descriptive level, the social worker's occupational profile includes three components: professional skills; professional roles; professional competences.

Social work in Bulgaria is not closed for „foreign impacts”. It is affected by universalized and unified tendencies of globalization. International organizations related to professional community of social workers and social work schools are very attractive in professional exchange. Their contribution is the adoption of the international definition of social work (as discussed above) as well as the initiative for fabricating and establishing work qualification standards.

In the Eastern European countries European-American theories and applied methods of social work are introduced. With this conditions are established for renewing the bureaucratized state social assistance systems. At the same time a cultural and professional exchange is performed which places the practice in those countries on new grounds. Through the financial and methodic assistance received according to various projects and programs the countries of Eastern Europe modernize their systems by adopting western models in social assistance.

European Union promotes the efforts of those countries suggesting mechanisms for institutional construction of their administrations. It funds the internal reforms by giving them opportunities to create certain or transform already existing structures which to obtain support through access to practices - experts with experience in the respective field. This way, for example, in the beginning of 2002 an 
agreement was signed between Bulgaria and Austria for institutional construction of Child Protection State Agency and municipals child protection divisions.

In the last years in Bulgaria experts are working from the USA, Great Britain, Scotland, France, Denmark, Austria, Germany. Undoubtedly the pluralism of ideas is useful but also confusing in cases when there is no clear view of what shall be achieved. The suggested social work models require careful analysis by taking into consideration the differences in societies with regards to ethnic cultural traditions and life philosophy. Models suggest different than local social, economic and institutional conditions. They can be hardly used without material modification and adaptation to the Bulgarian environment, observing the traditions, experience and training of social workers.

The aforementioned underlines the topicality of the questions: What expert/ professional the social worker in Bulgaria is? What are the needs of continuous professional training with the purpose of increasing the quality and efficiency of social work as a whole?

Outlining the professional profile of the social worker in Bulgaria is a research problem with two possible approaches. They are preconditioned on the specific peculiarities of the country. They report the fact that social work exists in Bulgaria recently and this is why, even though to a different extend, seek specific cross points between the practices and existing theoretic settings. Inevitably in both approaches reference is made to the practice of countries with a history in social work. The first approach is the way of analogy with countries where social work has a long tradition. As a result of research and analysis of their practice is synthesized profile - model, and the profile of Bulgarian social worker seems to be based on "deviations" from ideal. The second approach focuses on accepted national views on the nature and content of social work and general profession values (confidentiality, non-discrimination, solidarity, legality, loyalty to the organization, colleagues, customers, society, profession and so on). On this basis a profile is set - a model in which professionally significant features of the social worker are a function of social practice in Bulgaria.

Merdzhanova and Gospodinov [6] maintain the first approach in their research on professional peculiarities of social workers. They synthesize a descriptive model based on psychological estimates of several occupations that are modern in Bulgaria during recent years and western researches on work of social workers. The model described the social worker with:

\section{professional}

roles:

consultant, intermediary for obtaining social services, advocate, intermediary for obtaining social assistance, activist, communication intermediary, proxy, teacher, imitator, coordinator, researcher, organizer of work with groups, public spokesman.

\section{- professional competences:}

direct intervention when working with individual clients,

- main groups of professional abilities: scientific and scientific and applicable, diagnostic, methodic, communication, information, management, work with documentation.

The second approach is adopted in this paper. Attempting to construct the professional profile of the social worker here established is a descriptive model reporting national views of social work as well as set in various normative documents, government strategies and programs. They determine the framework which social work in Bulgaria is developed in. The analysis suggests the striving to adequately combine the available national resources with the EU requirements. The thesis is adopted that within the European social model every country looks for the most appropriate 
solutions which comply with the specifics of the economic, financial, social and demographic conditions and perspectives as fundamental ideas, principles and targets are similar.

The selected approach to the research problem allows underlining the common in the professional social activity, based on values valid for everyone practicing it and related to the designation of social work (to defend the weakest society members and support all citizens to maintain an independent way of life) and its professional philosophy (care for the potential growth of every personality; respect to all personality, faith in dignity and value of every individual; empowering the weak and marginalized) as at the same time outlines the specific in the model of social work while reporting the social, economic and institutional conditions where it is practiced.

The approach takes into consideration that the development of social work in Bulgaria is affected by the connections and interactions between processes of indemnifications, institutionalization, internalization and unification, generated by social-economic transformations in society and our membership in the European Union.

The design of professional social activity in Bulgaria is the fruit of economic and political considerations which effect on it is in direction of reasonable sufficiency, maximal efficiency, transparency, accessibility and reporting. It is accepted is a tool of social change which contributes to the social cohesion, social solidary and control over inequalities with review of optimizing the social relations and active maintenance of social balance.

According to the Social Assistance Act of the Republic of Bulgaria social workers immediately realize the social assistance tasks. They provide services based on individual approach and assessment of specific needs of people and families. They aim to improve the mutual adaptation of people and the environment they live in order to reach better quality of life, dignity and responsibility based on individual abilities, inter-personal relations and resources of community such as:

- satisfy the main vital needs that the person cannot do for himself;

- strengthen and develop the social solidarity in hard everyday situations;

- $\quad$ assist the social re-integration and employment;

- promote the development of alternative social services.

The realization in full of the stated tasks imposes to social workers also the following professional roles:

1. Work with the client in order to estimate his/her needs. Social workers are at the entrance of the social assistance system. They determine the access according to the established criteria. They are required to have the necessary competence with regards to information they collect as well as to contact they make.

2. Work with the client in order to overcome specific hindering situation (the so-called case work). Social workers implement activities with regards to specific client and vulnerable groups in society. They are engaged in rendering assistance and services. They develop individual plans, realize them and estimate the results of the basis of work relations with the client and teamwork. They plan, organize and control their own work and the work of others with the purpose of reaching set goals; dedication to work and abilities to work under pressure.

3. Risk management. Social workers encounter serious problems with people causing troubles. Necessary is to recognize the risk for themselves, for the client and others and they shall be able to avoid and minimize it. This is related to determining, estimating and analyzing risk; balancing the rights and responsibilities related to risk; undertaking specific actions, risk monitoring; observing the safety procedures.

4. Professional development. Social 
workers shall show responsibility towards their professional training, criticism towards their actions and increase their professional qualification with review the changes in social assistance policy. Introduction of new services and requirements towards their activity imposes constant perfecting and continuous training. Strive to success and willingness to develop their potential.

5. Work at organization. The social worker is member of the employment team/group. $\mathrm{He} / \mathrm{she}$ works with colleagues in a team, observes the employment discipline, maintains work documentation in appearance confirmed by the organization. $\mathrm{He} / \mathrm{she}$ works according to the organization's policy.

6. Support of the client. Social workers, on behalf and in favor of the client, defend his rights and express their needs and opinion, cooperate with the clients to organize and set their demands.

The so-defined professional roles position social workers as oppose to clients, own institution, other experts and institutions, engaged in implementing social policy, respective social assistance policy. The first two groups regard direct work with the client, the second two are related to risks in occupation and professional development and assure effective implementation of groups 1 and 2 as well as groups 5 and 6 . This way they form a core of activities above which constructed are the latter two, related to functional roles regard to the work of the social worker as employer of organization on one hand and at the same time representative of clients on the other. Upon realization of professional roles and competences the social worker steps on professional ethics and values. Their execution requires of the social worker analyticity, emotional intelligence, empathy, social literacy, constant maintenance of knowledge, high civil, social and political responsibility.

\section{CONCLUSION}

Missing are profound researches on the occupation of social work, professional profile and qualification of social worker in Bulgaria as well as the necessity of constant maintaining continuous training. Throughout recent years professionally significant characteristics of the Bulgarian social worker dynamically change with review of the accelerated bringing of social legislation in compliance with the once of the EU member-states. The social worker profile is outlines in the process as sought are cross points between the practice in Bulgaria and the EU member-states.

In the Bulgarian conditions professional competences of social worker are in three directions - direct work with clients, work in organization, work with colleagues, other experts and institutions. At the front are the priority functions - consulting, intermediary, coordination and management. Priority access to social assistance and services, maintenance and increase of professional awareness and qualification, observing the state institutional policy and priorities, teamwork.

The aforementioned allows making a statement that social workers are engaged with social work, expressed in providing social assistance, social services and activities of social integration and defense of people and families. Their professionally significant characteristics are in compliance with the degree of institutionalization of occupation social worker in Bulgaria and extending the professional area.

\section{References}

[1] Dimitrova, S., V. Terziev, Predlozheniya v oblasti sotsialynogo kapitala, partnerstva i seti. Razvitie sotsialynoy ekonomiki. Podderzhka sotsialynoy innovatsii, Mezhdunarodnaya nauchno-prakticheskaya konferentsiya „Ekonomicheskie nauki: teoreticheskiy i prakticheskiy vzglyad", 1 oktyabrya 2014, Ufa, Rossiya, pp.37-42. 
[2] Dimova, L. Social workers for their work, Bulletin No 2, May 2007, Ministry of Labor and Social Policy.

[3] DoH, Personal Social Services Personnel of Social Services Departments, London, Department of Health, 2013.

[4] International Federation of Social Workers: http://ifsw.org/.

[5] Kotseva M., V. Terziev, Z. Andreeva, Problemi na otsenkata na aktivnite politiki na pazara na truda, Peta natsionalna konferentsiya ,Sluzhbite po zaetostta i Evropeyskiya pazar na truda”, Rusenski universitet „Angel Kanchev”, MTSP, AZ, Ruse, 29-30 may 2003 g., str.9-13.

[6] Merdzhanova, Y., B. Gospodinov, For the Professional Profile of Social Worker, magazine „Strategies of Educational and Scientific Policy”, issue No 1, 2003.

[7] Nanyova, Ts., V. Terziev, Osiguryavane na zaetost na litsa v neravnostoyno polozhenie. Finansovo stimulirane na rabotodateli za razkrivane na novi rabotni mesta. Adaptivnost imobilnost na rabotnata sila, Yubileyna mezhdunarodna konferentsiya ,Trudat i negovata zashtita prezXXI vek", Universitet za natsionalno i svetovno stopanstvo, Sofiya, 29 may 2003 g., str. 288-300.

[8] Social Assistance Act of the Republic of Bulgaria.

[9] Terziev, V., A. Delibasheva, Sotsialna podkrepa i partnyrstvo v sferata na profesionalnoto orientirane za mladezhi i vazrastni, Parva nauchno-prakticheska konferentsiya s mezhdunarodno uchastie „Mrezhi za profesionalno orientirane za mladezhi i vazrastni”, Ikonomicheski universitet, Varna, 4-5 yuni 2003 g., str. 3-12.

[10] Terziev, V., E. Arabska, Aktivnite transformatsii v politikite za funktsionirasht pazar na truda i za zaetost. Nauchna konferentsiya $\mathrm{s}$ mezhdunarodno uchastie „Inovatsii $\mathrm{v}$ obrazovanieto“, 25-27 septemvri2015g. SHU „Episkop Konstantin Preslavski“. Godishnik na SHU „Ep. Konstantin Preslavski“, t.XIXD Pedagogicheski fakultet, Nauchni trudove ot konferentsiya, str. 96-104.

[11] Terziev, V., E. Arabska, Izgrazhdaneto na funktsionirasht pazar na truda v perioda na prehod na balgarskata ikonomika. Nauchna konferentsiya s mezhdunarodno uchastie „Inovatsii v obrazovanieto“, 25-27 septemvri 2015g. SHU „Episkop Konstantin Preslavski“. Godishnik na SHU „Episkop Konstantin Preslavski“, t. XIXD Pedagogicheski fakultet, Nauchni trudove ot konferentsiya, str. 82-95.

[12] Terziev, V., E. Arabska, Monitoring na aktivnite politiki na pazara natruda v Balgariya, Parva nauchno-prakticheska konferentsiya s mezhdunarodno uchastie „Sotsialna rabota, menidzhmant i sotsialno razvitie: savremenni predizvikatelstva, perspektivi i inovativni praktiki 2015", 1-2 oktomvri 2015, TU-Varna, str. 32-39.

[13] Terziev, V., E. Arabska, Sotsialnoto programirane v konteksta na nasarchavane na sotsialnata aktivnost. Yubileyna mezhdunarodna nauchna konferentsiya „Sotsialnite nauki i razvitieto na obshtestvoto - teoretichni i prakticheski izmereniya", Svishtov, 3031 oktomvri 2015 g., str.228-233.

[14] Terziev, V., I. Avramova, Sotsialnata politika v konteksta na Evropeyskata integratsiya i realizirane na izsledvane na vazmozhnostite za vavezhdane na tehnologiyata „Plan za deystvie", Sbornik s dokladi ot IV-ta Natsionalna nauchno-prakticheska konferentsiya „Sluzhbite po zaetostta i novite predizvikatelstva za realizirane na aktivnata politika na pazara na truda", 14-15 may 2002 g., Ruse, str. 13-21.

[15] Terziev, V., Kriterii i pokazateli za sotsialna efektivnost, Mezhdunarodna nauchna konferentsiya, Sbornik dokladi, tom III, Gabrovo, UNITEH 16-17 noemvri 2012 g., str. 231-240. 
[16] Terziev, V., Noviyat sotsialen model, kato efektivna vazmozhnost za realizirane na aktivnata politika na pazara na truda $\mathrm{v}$ Balgariya, Natsionalna nauchno-prakticheska konferentsiya „Gavkavata zaetost i problemi na neynata regulatsiya”, Plovdivski universitet „Paisiy Hilendarski”, Plovdiv, 4 yuli 2003 g., str. 56-71.

[17] Terziev, V., Obsht analiz na vazdeystvieto na programata „Ot sotsialni pomoshti kam osiguryavane na zaetost" na natsionalniya trudov pazar, UNITEH'05, Gabrovo, 24-25 noemvri 2005 g. Tom III, str.75-80.

[18] Terziev, V., Obshtinite i sotsialnoto podpomagane, Informatsionen byuletin „Reformata v mestnoto samoupravlenie“", br.12, Fondatsiya zareforma v mestnoto samoupravlenie, Sofiya, $2002 \mathrm{~g}$.

[19] Terziev, V., Prilozhenie na sotsialnoto programirane $\mathrm{v}$ reguliraneto na sotsialnoto razvitie: efektivni sotsialni politiki chrez nasarchavane na sotsialnata aktivnost na choveshkiya resurs. Godishnik/SA „D. A. Tsenov”, Tom SHIX, Svishtov 2016, str. 791.

[20] Terziev, V., S. Dimitrova, Opredelyane na kriterii i pokazateli za sotsialna efektivnost, Yubileyna nauchna konferentsiya 2014,100 godiniaviatsionno obrazovanie V Balgariya”, Natsionalen voenen universitet „Vasil Levski”, 9-10 oktomvri 2014g., gr.Dolna Mitropoliya, str.195-209.

[21] Terziev, V., S. Dimitrova, Rolyata na sotsialnata politika v ikonomicheskoto razvitie, Yubileyna nauchna konferentsiya 2014,100 godiniaviatsionno obrazovanie V Balgariya”, Natsionalen voenen universitet „Vasil Levski”, 9-10 oktomvri 2014 g., gr.Dolna Mitropoliya, str. 228-239.

[22] Terziev, V., Sotsialnoto programirane $\mathrm{v}$ sistemata na sotsialnite kategorii, VII Mezhdunarodnaya nauchnaya konferentsiya „Innovatsii v tehnologiyah i obrazovanii” (KuzGTU), Belovo, Rossiya, 2014. Sbornik statey chasty 2, pp.289-298.

[23] Terziev, V., Yu. Mladenov, Aktivna sotsialna programa i neynoto strategichesko preimushtestvo, Nauchni trudove na Rusenski universitet „Angel Kanchev”, Tom 51, seriya 5.1., Ruse, 2012 g., str. 9-14.

[24] Terziev, V., Yu. Mladenov, M. Stoychev, Izsledvane vazmozhnostite za trudovata reintegratsiya na prodalzhitelno bezrabotni litsa na pazara na truda chrez programa za zaetost, UNITEH'04, Gabrovo, 18-19 noemvri 2004 g. Tom III, str.62-66.

[25] Zastrow, C. H. The Practice of Social Work, Brooks/Cole Publishing Co., Passific Grove, 1999. 